\title{
Safeguard Clothing and Dive Decrease
}

\author{
D.Jeyapriya, G.Michael, R.Elankavi , Stephen Anto Jijo
}

\begin{abstract}
Conceptual-Security is one of the significant issues which the present progressed IoT dangers require a point by point episode reaction methodology when complex hacking assaults. This paper presents clear and particular lightweight high connection honeypot with checksum approach can examine additionally moderate undetected security dangers.Urban communities around the globe are dynamically getting to be noticeably brilliant as anyone might expect, It's been IoT (Internet of Things) to IoE (Internet of Every Thing) time, Sapless security may influence the lives of a large number of clients protection, Security and Trust. 2015 has additionally been the time of worldwide digital settlements to help hinder assaults

Index Terms: Vectors, Virus, IOT
\end{abstract}

\section{INTRODUCTION}

Security dangers are wherever the run of the mill Insider [2 ], [ 4],[6] dangers or Zero-day assault keeps going a normal of eight months or years without knowing it. That release assaults satisfactory time to take significant resources . Because of number and kinds of vulnerabilities proceeding to develop exponentially with the engendering of rise of IoT(Internet of Things), Bring Your Own Device (BYOD).Intrusion location framework (IDS), Anti-virus(AV) and knowledge encourages produce so much information innovations to gather, dissect, and report information arrange design is just a large portion of the fight, executes controls. The presentIoT related dangers require a nitty gritty occurrence reaction procedure when it makes a difference[1],[3],[5] to take after when you progress toward becoming broken. The staying of the paper is sorted out as takes after. In [8],[ 10], [12]segment 2 writing review talk about ENISA top danger Landscape patterns. Issue definition on area 3 . Segment 4 proposed strategy on segment 5 and 6 manages the examination setup and perceptions comes about. [7],[9],[11]

All around conveyed sensors can be precious apparatuses in the safeguards stockpile mean to uncover assailant devices, systems and unfamiliar vectors, by entangling aggressors through copying of normal conventions and benefits and don't have to look anything like the honeypots of old. [13], [15], [17]

Revised Manuscript Received on July 22, 2019.

D.Jeyapriya,, Department of Computer Science and Engineering, Bharath Institute of Higher education and research, Chennai, India

G.Michael,Department of computer science and engineering ,Bharath Institute of Higher Education and Research, Chennai Thamilnadu, India.

R.Elankavi Department of computer science and engineering,Bharath Institute of Higher Education and Research,Chennai, Thamilnadu,,India.

Stephen Anto Jijo, Department of computer science and engineering,Bharath Institute of Higher Education and Research,Chennai, Thamilnadu,,India.

\section{MATERIALS AND METHODOLOGY}

Inadequate security abilities and troubles for fixing vulnerabilities in these gadgets, and an absence of customer security mindfulness, furnish digital performing artists with chances to abuse these gadgets. Culprits can utilize these chances to remotely encourage assaults on different frameworks, send noxious and spam messages, take individual data, or meddle with physical safety. [14],[ 16], [18]

\section{A. TheIoT elements:}

A misuse of the Universal Plug and Play convention (UPnP) to access numerous IoT gadgets. UPnP is intended to self-design when appended to an IP address, making it powerless against abuse. Digital performing artists can change the design, and run charges on the gadgets, possibly empowering the gadgets to gather touchy data or lead assaults against homes and organizations, or participate in computerized eavesdropping;[7]. [19],[21],[23]

\section{B. Conceivable Attack Vectors}

An abuse of default passwords to send malignant and spam messages, or take .Urban communities around the globe are continuously getting to be plainly savvy as anyone might expect, It's been IoT (Internet of Things) to IoE (Internet of Every Thing) period, Sapless security may influence the lives of a large number of clients protection, Security and Trust. 2015 has additionally been the time of worldwide digital bargains to help block assaults. Security dangers are wherever the run of the mill Insider Well sent sensors can be significant apparatuses in the protectors armory intend to uncover assailant instruments, strategies and unfamiliar vectors, by entangling aggressors through copying of basic conventions and benefits and don't have to look anything like the honeypots of old[20],[22], [24]

\section{RESULTS AND DISCUSSIONS}

Inadequate security capacities and troubles for fixing vulnerabilities in these gadgets, and also an absence of purchaser security mindfulness, furnish digital on-screen characters with chances to abuse these gadgets. Offenders can utilize these chances to remotely encourage assaults on different frameworks, send vindictive and spam messages, take individual data, or meddle with physical safety. [25],[27],[29] 


\section{A. TheIoT progression}

An abuse of the Universal Plug and Play convention (UPnP) to access numerous IoT gadgets. UPnP is intended to self-design when joined to an IP address, making it helpless against misuse. Digital performing artists can change the setup, and run summons on the gadgets, conceivably empowering the gadgets to reap delicate data or direct assaults against homes and organizations, or take part in advanced eavesdropping;. [26],[28],[30]

\section{B. Conceivable Attack Vectors}

A misuse of default passwords to send noxious and spam messages, or take A physical honeypot is a certifiable host machine alone specific IP are frequently high-collaboration, so enabling the sensors to be completely bargained, The estimation of a honeypot is controlled by the information that we can get from it, They are costly to introduce and keep up for huge address spaces, it is unfeasible to send a physical honeypot for every IP address on each IoT gadgets, for example, single board PCs. [31],[33],[35]

All things considered, Deploy virtual honeypots to identify malevolent conduct, NIDS (Network Intrusion Detection System) require marks of known assaults and regularly neglect to distinguish bargains that were obscure at the time it was sent. [32],[34],[36]

Then again, honeypots can distinguish vulnerabilities that are not yet caught on. Thus, scientific examination of information gathered from nectar pots is less inclined to prompt false positives than information gathered by NIDS bringing honeypots back a marvelous idea tempered by finished decade of glorious misapplication bringing about an ease back assignment to the domain of the scholarly world and somewhat questionable research, [37],[39],[41]

Be that as it may, it doesn't need to be that way in light of the fact that a honeypot has genuine generation esteem. [38],[40]

\section{CONCLUSIONS}

Secluded and decentralized open source honeypot endeavor to contact suspicious to investigate different assaults viewing the honeypot as an inward conveyed sensor as opposed to an independent caution generator.[8]

Every occasion announced is an amazing pointer of examination commendable movement and each open canary example nourishes occasion information to a correlators which produces single cautions even notwithstanding system wide outputs. With such a high flag to-commotion proportion, each alarm requires examination. This is rather than the surge of cautions delivered by instruments, for example, hostile to infection, organize IDS or customary honeypots.
A few Popular programming dialects and Linux based frameworks transports a few inherent usefulness including hashing utilities like md5 (md5sum) sh1 et cetera., Shell contents and cron occupations awesome way computerize hash age and examination for an extensive number of records on the framework to check its uprightness. The first application source code record hashes are created and tried over all on generation hubs if any progressions are found on checksum esteem rather the trusted hash esteems from unique source document can be effortlessly identified and proceed additionally activity on it. The aggregates are registered as portrayed in RFC 1321.

For the proactive assurance nectar tokens helps track movement and activities on your system by turning up dockerized canary tokens holder requires At slightest one open IP and Domain name.

Arrange A record compose on DNS records if utilizing Top-level area (TLD) or ccTLD (nation code top-level space) or add CNAME record write to DNS (Domain Name System) records on the off chance that you are utilizing sub area agreeing your necessities and sit tight for proliferation changes on DNS after visit enter your email and tag and snap produce catch and you prepared to trigger the created tokens by means of a few distinctive courses assortment of ways, including email addresses, DNS asks for on cloned sites, Social Networking profiles, database questions and changes.

\section{REFERENCES}

[1] Kumarave A., Rangarajan K.,Algorithm for automaton specification for exploring dynamic labyrinths, Indian Journal of Science and Technology,V-6,I-SUPPL5,PP-4554-4559,Y-2013

[2] P. Kavitha, S. Prabakaran "A Novel Hybrid Segmentation Method with Particle Swarm Optimization and Fuzzy C-Mean Based On Partitioning the Image for Detecting Lung Cancer" International Journal of Engineering and Advanced Technology (IJEAT) ISSN: 2249-8958, Volume-8 Issue-5, June 2019

[3] Kumaravel A., Meetei O.N.,An application of non-uniform cellular automata for efficient cryptography,2013 IEEE Conference on Information and Communication Technologies, ICT 2013,V-,I-,PP-1200-1205,Y-2013

[4] Kumarave A., Rangarajan K.,Routing alogrithm over semi-regular tessellations,2013 IEEE Conference on Information and Communication Technologies, ICT 2013,V-,I-,PP-1180-1184,Y-2013

[5] P. Kavitha, S. Prabakaran "Designing a Feature Vector for Statistical Texture Analysis of Brain Tumor" International Journal of Engineering and Advanced Technology (IJEAT) ISSN: 2249-8958, Volume-8 Issue-5, June 2019

[6] Dutta P., Kumaravel A.,A novel approach to trust based identification of leaders in social networks, Indian Journal of Science and Technology,V-9,I-10,PP--,Y-2016

[7] Kumaravel A., Dutta P.,Application of Pca for context selection for collaborative filtering,Middle - East Journal of Scientific Research,V-20,I-1,PP-88-93,Y-2014

[8] Kumaravel A., Rangarajan K.,Constructing an automaton for exploring dynamic labyrinths,2012 International Conference on Radar, Communication and Computing, ICRCC 2012,V-,I-,PP-161-165,Y-2012

[9] P. Kavitha, S. Prabakaran "Adaptive Bilateral Filter for Multi-Resolution in Brain Tumor Recognition" International Journal of Innovative Technology and Exploring Engineering (IJITEE) ISSN: 2278-3075, Volume-8 Issue-8 June, 2019

[10] Kumaravel A.,Comparison of two multi-classification approaches for detecting network attacks, World Applied Sciences Journal,V-27,I-11,PP-1461-1465,Y-2013

[11] Tariq J., Kumaravel A.,Construction of cellular automata over hexagonal and triangular tessellations for path planning 
multi-robots,2016 IEEE International Conference on Computational Intelligence and Computing Research, ICCIC 2016,V-,I-,PP--,Y-2017

[12] Sudha M., Kumaravel A.,Analysis and measurement of wave guides using poisson method,Indonesian Journal of Electrical Engineering and Computer Science,V-8,I-2,PP-546-548,Y-2017

[13] Ayyappan G., Nalini C., Kumaravel A.,Various approaches of knowledge transfer in academic social network,International Journal of angineering and Technology,V-,I-,PP-2791-2794,Y-2017

[14] Kaliyamurthie, K.P., Sivaraman, K., Ramesh, S. Imposing patient data privacy in wireless medical sensor networks through homomorphic cryptosystems 2016, Journal of Chemical and Pharmaceutical Sciences 92.

[15] Kaliyamurthie, K.P., Balasubramanian, P.C. An approach to multi secure to historical malformed documents using integer ripple transfiguration 2016 Journal of Chemical and Pharmaceutical Sciences 92 .

[16] A.Sangeetha,C.Nalini,"Semantic Ranking based on keywords extractions in the web", International Journal of Engineering \& Technology, 7 (2.6) (2018) 290-292

[17] S.V.GayathiriDevi,C.Nalini,N.Kumar,"An efficient software verification using multi-layered software verification tool "International Journal of Engineering \& Technology, 7(2.21)2018 454-457

[18] C.Nalini,ShwtambariKharabe,"A Comparative Study On Different Techniques Used For Finger - Vein Authentication", International Journal Of Pure And Applied Mathematics, Volume 116 No. 8 2017, 327-333, Issn: 1314-3395

[19] M.S. Vivekanandan and Dr. C. Rajabhushanam, "Enabling Privacy Protection and Content Assurance in Geo-Social Networks", International Journal of Innovative Research in Management, Engineering and Technology, Vol 3, Issue 4, pp. 49-55, April 2018

[20] Dr. C. Rajabhushanam, V. Karthik, and G. Vivek, "Elasticity in Cloud Computing", International Journal of Innovative Research in Management, Engineering and Technology, Vol 3, Issue 4, pp. 104-111, April 2018.

[21] K. Rangaswamy and Dr. C. Rajabhushanamc, "CCN-Based Congestion Control Mechanism In Dynamic Networks", International Journal of Innovative Research in Management, Engineering and Technology, Vol 3, Issue 4, pp. 117-119, April 2018.

[22] Kavitha, R., Nedunchelian, R., "Domain-specific Search engine optimization using healthcare ontology and a neural network backpropagation approach", 2017, Research Journal of Biotechnology, Special Issue 2:157-166

[23] Kavitha, G., Kavitha, R., "An analysis to improve throughput of high-power hubs in mobile ad hoc network" , 2016, Journal of Chemical and Pharmaceutical Sciences, Vol-9, Issue-2: 361-363

[24] Kavitha, G., Kavitha, R., "Dipping interference to supplemen throughput in MANET", 2016, Journal of Chemical and Pharmaceutical Sciences, Vol-9, Issue-2: 357-360

[25] Michael, G., Chandrasekar, A.,"Leader election based malicious detection and response system in MANET using mechanism design approach", Journal of Chemical and Pharmaceutical Sciences(JCPS) Volume 9 Issue 2, April - June 2016

[26] Michael, G., Chandrasekar, A.,"Modeling of detection of camouflaging worm using epidemic dynamic model and power spectral density", Journal of Chemical and Pharmaceutical Sciences(JCPS) Volume 9 Issue 2, April - June 2016.

[27] Pothumani, S., Sriram, M., Sridhar, J., Arul Selvan, G., Secure mobile agents communication on intranet,Journal of Chemical and Pharmaceutical Sciences, volume 9, Issue 3, Pg No S32-S35, 2016

[28] Pothumani, S., Sriram, M., Sridhar, Various schemes for database encryption-a survey, Journal of Chemical and Pharmaceutical Sciences, volume 9, Issue 3, Pg NoS103-S106, 2016

[29] Pothumani, S., Sriram, M., Sridhar, A novel economic framework for cloud and grid computing, Journal of Chemical and Pharmaceutical Sciences, volume 9, Issue 3, Pg No S29-S31, 2016

[30] Priya, N., Sridhar, J., Sriram, M. "Ecommerce Transaction Security Challenges and Prevention Methods- New Approach" 2016 Journal of Chemical and Pharmaceutical Sciences, JCPS Volume 9 Issue 3.page no:S66-S68 .

[31] Priya, N.,Sridhar,J.,Sriram, M."Vehicular cloud computing security issues and solutions" Journal of Chemical and Pharmaceutical Sciences(JCPS) Volume 9 Issue 2, April - June 2016
[32] Priya, N., Sridhar, J., Sriram, M. "Mobile large data storage security in cloud computing environment-a new approach" JCPS Volume 9 Issue 2. April - June 2016

[33] Anuradha.C, Khanna.V, "Improving network performance and security in WSN using decentralized hypothesis testing "Journal of Chemical and Pharmaceutical Sciences(JCPS) Volume 9 Issue 2, April - June 2016 .

[34] Anuradha.C, Khanna.V, "A novel gsm based control for e-devices" Journal of Chemical and Pharmaceutical Sciences(JCPS) Volume 9 Issue 2, April - June 2016 .

[35] Anuradha.C, Khanna.V, "Secured privacy preserving sharing and data integration in mobile web environments " Journal of Chemical and Pharmaceutical Sciences(JCPS) Volume 9 Issue 2, April - June 2016 .

[36] Sundarraj, B., Kaliyamurthie, K.P. Social network analysis for decisive the ultimate classification from the ensemble to boost accuracy rates 2016 International Journal of Pharmacy and Technology 8

[37] Sundarraj, B., Kaliyamurthie, K.P. A content-based spam filtering approach victimisation artificial neural networks 2016 International Journal of Pharmacy and Technology $\quad 8 \quad 3$.

[38] Sundarraj, B., Kaliyamurthie, K.P. Remote sensing imaging for satellite image segmentation 2016 International Journal of Pharmacy and Technology 83 .

[39] Sivaraman, K., Senthil, M. Intuitive driver proxy control using artificial intelligence 2016 International Journal of Pharmacy and Technology 84

[40] Sivaraman, K., Kaliyamurthie, K.P. Cloud computing in mobile technology2016 Journal of Chemical and Pharmaceutical Sciences 92.

[41] Sivaraman, K., Khanna, V.Implementation of an extension for browser to detect vulnerable elements on web pages and avoid click jacking 2016 Journal of Chemical and Pharmaceutical Sciences 92

\section{AUTHORS PROFILE}

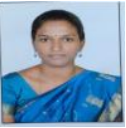

D.Jeyapriya, Assistant Professor, Department of Computer Science \& Engineering, Bharath Institute of Higher Education and Research, Chennai, India

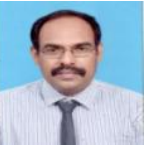

Michael, Associate Professor,Department of CSE, Bharath Institute of Higher Education and Research, Chennai, Tamilnadu, India.

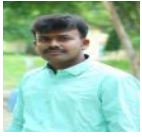

R.Elankavi, Assistant Professor, Department of Computer Science \& Engineering, Bharath Institute of Higher Education and Research, Chennai, India

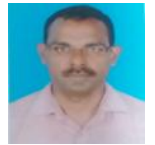

Stephen Anto Jijo, Assistant Professor, Department of Computer Science \& Engineering, Bharath Institute of Higher Education and Research, Chennai, India 